\title{
On the road again: traffic fatalities and auto insurance minimums
}

PAVEL A. YAKOVLEV, Ph.D.*

CHRISTINA M. ORR-MAGULICK*

Article**

JEL: G22, H7, J28, K13

doi: 10.3326/fintp.42.1.3

\footnotetext{
* We thank Dr. Kevin Shaver and research assistant Josef DiPietrantonio for their invaluable help. We would also like to thank the anonymous referees for useful comments and suggestions.

${ }^{* *}$ Received: May 22, 2017

Accepted: November 15, 2017
}

Pavel A. YAKOVLEV

Associate Professor, Department of Economics and Finance, Duquesne University, Rockwell Hall 909, 600 Forbes Ave, Pittsburgh, PA 15282, USA

e-mail: yakovlevp@duq.edu

ORCiD: 0000-0003-0447-1726

Christina M. ORR-MAGULICK

Associate, Gordon Rees Scully Mansukhani, 707 Grant Street, Suite 3800, Pittsburgh, PA 15219, USA

e-mail: cmagulick@grsm.com

ORCiD: 0000-0001-8420-0648 


\section{Abstract}

Prior research on policy-induced moral hazard effects in the auto insurance market has focused on the impact of compulsory insurance, no-fault liability, and tort liability laws on traffic fatalities. In contrast, this paper examines the moral hazard effect of a previously overlooked policy variable: minimum auto insurance coverage. We hypothesize that state-mandated auto insurance minimums may "over-insure" some drivers, lowering their incentives to drive carefully. Using a longitudinal panel of American states from 1982 to 2006, we find that policyinduced increases in auto insurance minimums are associated with higher traffic fatality rates, ceteris paribus.

Keywords: traffic fatalities, auto insurance, minimums, moral hazard

\section{INTRODUCTION}

In the United States, compulsory insurance laws mandate that drivers must purchase some minimal amount of liability coverage. These state-specific auto insurance minimums have remained unchanged in nominal value in most states since their enactment in 1967. The required insurance minimums contain three separate numbers. The first number specifies the per-person amount of medical liability, the second number specifies the maximum amount of medical liability per accident, and the third number specifies the amount of property liability. For example, Alaska's required auto insurance minimums of 50/100/25 (in thousands of dollars) are some of the highest in the nation, while Mississippi's insurance minimums of 25/50/25 are some of the lowest.

As the real value of these fixed insurance minimums continues to decline over time due to inflation, some drivers may find the reduced amount of insurance more appropriate for their risk level, while those who desire more coverage can easily choose to add more. In other words, the mandated auto-insurance minimum can be thought of as a price-floor, the binding value of which has been eroding over time due to inflation. In light of this, several states have increased their minimum liability insurance amounts in recent years. This mandated increase in coverage may effectively over-insure some drivers, reducing their incentive to drive carefully. Economists have long hypothesized that some features of auto insurance policy can create a perverse incentive, an effect commonly known as moral hazard.

To the best of our knowledge, this study is the first to examine whether the recent increases in state-level auto insurance minimums can increase the traffic fatality rate. The logic behind our hypothesis is rather simple: if the required insurance coverage exceeds the optimal amount preferred by some drivers, then they become over-insured and have less of an incentive to drive carefully. The expected result is a positive relationship between state traffic fatality rate and higher auto insurance minimums, holding everything else constant. We test for the presence of this moral hazard effect in a longitudinal panel of American states from 1982 to 2006. We find that the hypothesized moral hazard effect is statistically different from zero, but 
relatively small in magnitude: a one percent increase in the average state auto insurance minimum is associated with about 0.1 percent increase in the traffic fatality rate, ceteris paribus. Still, even this relatively small effect implies that increasing the average liability minimum by $\$ 6,000$ would result in one extra traffic fatality, a questionable tradeoff given the average value of a statistical life of about $\$ 7$ million. Our estimate is consistent with the recent findings showing significant improvements in traffic safety and social welfare from less generous insurance coverage (Jeziorski, Krasnokutskaya and Ceccariniz, 2015; Weisburd, 2015).

\section{LITERATURE REVIEW}

While insurance plays a valuable role in a market economy and may even be a viable alternative to government regulation according to Logue and Ben-Shahar (2012), it can be significantly undermined by asymmetric information. Early seminal work by Arrow (1963), Akerlof (1970), and Pauly $(1968,1974)$ demonstrates that competitive insurance markets can be inefficient in the presence of asymmetric information, which occurs when one party knows more about a product or service being traded than the other party and tries to gain from that knowledge. This can lead to adverse selection and moral hazard, both of which lower the social efficiency of a market. In the auto insurance market, asymmetric information implies a positive correlation between a policyholder's accident probability and insurance generosity (Rothschild and Stiglitz, 1976; Wilson, 1977). This positive correlation can be attributed to either adverse selection or moral hazard (Abbring et al., 2003). In the case of adverse selection, the free market is likely to under-provide insurance due to suboptimal risk allocations (Puelz and Snow, 1994). Compulsory insurance laws are often viewed as the solution to the adverse selection problem that plagues the insurance market (Pauly, 1974). Compulsory insurance laws require that all drivers obtain insurance, thereby reducing insurance risk and adverse selection.

However, compulsory insurance laws may exacerbate the moral hazard problem if insurance premiums and coverage amounts do not properly reflect a customer's risk level. Moral hazard occurs when individuals do not bear the full cost of their actions, giving them an incentive to act in a more reckless fashion. If widespread, this tendency increases the cost of providing insurance to all individuals. In the case of auto insurance, moral hazard may lead to non-trivial costs in terms of greater property damage and more frequent traffic collisions (Shavell, 1979; Holmstrom, 1979). Arrow (1970) and Pauly (1968) propose two partial solutions to the moral hazard problem in insurance: incomplete coverage or closer monitoring (observing). Shavell (1979) argues that the optimal amount of coverage lies somewhere between full and partial coverage. Much of the following research has focused on reconciling the theoretical insights with empirical evidence.

In a seminal paper, Peltzman (1975) develops the famous risk compensation theory where individuals seek some optimal level of risk, making them counteract the gains in safety (risk reduction) by driving more aggressively. For example, a 
rise in seat belt usage may lead to more careless driving, potentially increasing traffic accidents and fatalities. Similarly, drivers in airbag-equipped vehicles might feel safer and drive less carefully as a result. Several studies have confirmed the so-called Peltzman compensation effect. ${ }^{1}$ For instance, Sen (2001) finds that Canadian mandatory seatbelt legislation did not reduce traffic fatalities by the predicted amount due to drivers offsetting some of the gains in safety from seatbelt usage by driving more aggressively. Harless and Hoffer (2003) show that the rise in personal injury claims after airbag adoption can be attributed to moral hazard and vehicle ownership pattern. They also find that rental car drivers are much more likely to commit grievous acts than other drivers. Some of the most conclusive evidence on the Peltzman compensation effect comes from the study of micro-level NASCAR data by Sobel and Nesbit (2007), who find that safety improvements in NASCAR racing have led to more reckless driving.

In contrast, the moral hazard effect stemming from auto insurance coverage has been more difficult to ascertain empirically. Abbring et al. (2003) demonstrate that a positive correlation between traffic fatalities and insurance coverage in static data can be interpreted as either moral hazard or adverse selection. Similarly, Cohen and Siegelman (2010) argue that the presence of a positive coverage-risk correlation in auto insurance markets can be indicative of both moral hazard and adverse selection because riskier drivers may buy more insurance (adverse selection), while more insurance coverage may also encourage reckless driving (moral hazard). Using dynamic experience-rated insurance data, Abbring, Chiappori and Pinquet (2003) claim to have been able to separate the moral hazard and adverse selection effects. Using non-parametric tests, they find no significant evidence of moral hazard in the French auto insurance market, but the coefficient's sign for younger policy holders is consistent with the moral hazard hypothesis despite not being statistically significant.

More recent studies, however, find increasing evidence of moral hazard in the auto insurance market. For example, Israel (2004) and Dionne et al. (2005) apply the Abbring, Chiappori and Pinquet (2003) methodology to longer data panels in the United States and Canada, respectively, and confirm the presence of moral hazard. Specifically, Dionne et al. show that the implementation of the new bonus-malus (experience-rating) scheme in Quebec's automobile insurance industry has lowered the moral hazard effect as evidenced by fewer collisions and traffic violations. Abbring, Chiappori and Zavadil (2008) study dynamic incentives of experience-rated policy and find evidence of moral hazard in the Dutch auto insurance market. Using data from the Quebec public insurance plan, Dionne et al. (2011) also find evidence that accumulated demerit points incentivize safer driving due to the threat of driver's license revocation. Furthermore, Dionne, Michaud and Dahchour (2013) use experience-rated, longitudinal survey data with dynamic information both on claims and accidents from France during the 1995-1997 period and find evidence of moral hazard among a subgroup of policyholders with

\footnotetext{
${ }^{1}$ See Garbacz (1990a, 1990b, 1991, 1992); Risa (1994); Calkins and Zlatoper (2001)
} 
less than 15 years of driving experience. This result suggests that more coverage for less experienced policyholders leads to a higher probability of a future accident, ceteris paribus. In their study, Dionne et al. also claim to be able to separate moral hazard from adverse selection and learning, noting that policyholders with less driving experience have a combination of learning and moral hazard effects. Weisburd's (2015) instrumental variable analysis of Israeli employer-determined auto insurance data from the 2001-2008 period shows that a $\$ 100$ reduction in accident costs for drivers results in a 1.7 percentage point increase in the probability of an accident or, equivalently, a 10 percent increase in auto accidents. Similarly, the Jeziorski, Krasnokutskaya and Ceccariniz (2015) analysis of data from a major Portuguese auto insurance company offers strong evidence of moral hazard. One of their key findings indicates that introducing a 20\% deductible can reduce the annual number of accidents by 1,518 . Their estimates suggest that switching from full to partial auto insurance coverage can significantly reduce the number of accidents and substantially improve social welfare. These findings are consistent with the standard theoretical conclusion that full insurance may not be optimal in the presence of moral hazard.

In contrast to the aforementioned literature, the moral hazard hypothesis examined in our paper is most closely related to a separate body of research on the aggregate-level safety effects of insurance policy changes. Several studies find that certain state auto insurance laws, like no-fault liability, may increase traffic collisions via the moral hazard effect. In a pure no-fault liability system, policyholders are reimbursed by policyholders' insurance companies without proof of fault and cannot seek extra damages through the justice system, which may introduce a perverse incentive to drive less carefully. Non-coincidentally, Landes (1982) finds that states with no-fault liability laws have more fatal accidents, holding everything else constant. However, Zador and Lund (1986) update Landes' study with more recent data and find no conclusive evidence that no-fault liability laws lead to more fatal accidents. Kochanowski and Young (1985) also arrive at the same conclusion. Cummins, Weiss and Phillips (2001) argue that the adoption of nofault liability laws can be endogenous in traffic collisions, which could explain these different findings. Using the instrumental variable approach, Cummins, Weiss and Phillips find that fatal accident rates are higher in states with no-fault liability laws, holding everything else constant. Similarly, Cohen and Dehejia (2004) find that reductions in accident liability due to no-fault laws have led to more traffic fatalities, which is indicative of moral hazard. In this paper, we set out to test whether higher auto insurance minimums set by policymakers can effectively over-insure some drivers and lead to an analogous moral hazard effect that can manifest itself in higher traffic accidents or fatalities. 


\section{DATA}

We set out to estimate a relationship between state traffic fatality rate and auto insurance minimums using a balanced panel of 48 American states from 1982 to 2006. Data availability for some important control variables dictates the chosen time period and states. For example, historic average precipitation and temperature, key control variables, are not currently available for all years for Alaska and Hawaii, excluding these two states from our regression analysis.

The dependent variable in our analysis is the annual traffic fatality rate (total traffic-related fatalities divided by state population). Traffic fatality data were obtained from the Fatal Accident Reporting System (FARS) made available by the National Highway Traffic and Safety Administration. Traffic fatalities, as opposed to collisions, are chosen for two reasons. First, traffic collisions without fatalities tend to be under-reported. ${ }^{2}$ States with higher insurance minimums tend to have more uninsured drivers, further accentuating the underreporting bias. ${ }^{3}$ Support for this argument comes from Ma and Schmit (2000), who find that higher poverty rates are associated with more uninsured drivers. Second, not all states measure and report traffic collisions in the same way, making it a very unrepresentative and unbalanced panel of states. For these reasons, we follow many other studies and use traffic fatalities instead of collisions.

The key variable of interest in this study is the mandatory minimum of auto insurance liability coverage that an insured driver must purchase, which varies from state to state and over time. There are three categories of minimal liability coverage that are required by each state: per person medical liability, per accident medical liability, and per accident property liability. In the event of an accident, the insured individual may receive up to the full amount of minimum coverage to help pay for medical care and property damages. Since all three minimum categories are strongly collinear ${ }^{4}$ within states, we use the inflation-adjusted per accident medical liability amount as the relevant measure of state auto insurance minimums (usually per accident amount is twice of per person amount).

Table 1 shows the nominal values, expressed in thousands, for the three categories of insurance minimums in each state in year 2006. First instituted in 1967, the insurance minimums have been increased by policymakers only in ten states during the studied time period (1982-2006). Inflation has significantly eroded the real value of these insurance minimums over time in most states, making them less binding for some drivers. ${ }^{5}$ At the same time, significant improvements in vehicle

\footnotetext{
${ }^{2}$ The National Highway Traffic Safety Administration estimates that over 10 million crashes go unreported each year. Insurance Research Council's Uninsured Motorists 2014 Edition reports that about 13 percent of drivers were uninsured in 2012, with Oklahoma topping the list with 26 percent and Massachusetts at the bottom with 4 percent.

${ }^{3}$ Consumer Federation of America claims that most uninsured drivers have low incomes and struggle to afford the high-priced minimum liability coverage now required by all states, except for New Hampshire.

${ }^{4}$ Pairwise correlation is 0.99 between per person and per accident medical liability and 0.63 between per person/accident medical and property liability.

${ }^{5}$ We adjust the nominal value of insurance minimums for inflation using the GDP deflator.
} 
and road safety over the years have led to a pronounced general decline in traffic fatality rates as well. As can be seen in figure 1, the average real value of per accident medical liability minimum and the average state traffic fatality rate have both fallen from 1982 to 2006 .

\section{TABLe 1}

State auto insurance minimums in 2006 (in thousands of U.S. dollars)

\begin{tabular}{|c|c|c|c|c|c|c|c|}
\hline State & $\begin{array}{c}\text { Per } \\
\text { person } \\
\text { liability }\end{array}$ & \begin{tabular}{c}
\multicolumn{1}{c}{ Per } \\
accident \\
liability
\end{tabular} & $\begin{array}{c}\text { Property } \\
\text { liability }\end{array}$ & State & $\begin{array}{c}\text { Per } \\
\text { person } \\
\text { liability }\end{array}$ & $\begin{array}{l}\text { Per } \\
\text { accident } \\
\text { liability }\end{array}$ & $\begin{array}{c}\text { Property } \\
\text { liability }\end{array}$ \\
\hline Alabama & 20 & 40 & 10 & Montana & 25 & 50 & 10 \\
\hline Alaska & 50 & 100 & 25 & Nebraska & 25 & 50 & 25 \\
\hline Arizona & 15 & 30 & 10 & Nevada & 15 & 30 & 10 \\
\hline Arkansas* & 25 & 50 & 25 & New Hampshire & 25 & 50 & 25 \\
\hline California & 15 & 30 & 5 & New Jersey & 15 & 30 & 5 \\
\hline Colorado & 25 & 50 & 15 & New Mexico & 25 & 50 & 10 \\
\hline Connecticut & 20 & 40 & 10 & New York* & 25 & 50 & 10 \\
\hline Delaware* & 15 & 30 & 10 & North Carolina & 30 & 60 & 25 \\
\hline Florida & 10 & 20 & 10 & North Dakota & 25 & 50 & 25 \\
\hline Georgia* & 25 & 50 & 25 & Ohio & 13 & 25 & 8 \\
\hline Hawaii & 20 & 40 & 10 & Oklahoma* & 25 & 50 & 25 \\
\hline Idaho & 20 & 50 & 15 & Oregon & 25 & 50 & 10 \\
\hline Illinois & 20 & 40 & 15 & Pennsylvania & 15 & 30 & 5 \\
\hline Indiana & 25 & 50 & 10 & Rhode Island & 25 & 50 & 25 \\
\hline Iowa & 20 & 40 & 15 & South Carolina* & 15 & 30 & 10 \\
\hline Kansas & 25 & 50 & 10 & South Dakota & 25 & 50 & 25 \\
\hline Kentucky & 25 & 50 & 10 & Tennessee & 25 & 50 & 10 \\
\hline Louisiana & 10 & 20 & 10 & Texas & 20 & 40 & 15 \\
\hline Maine & 50 & 100 & 25 & Utah* & 25 & 50 & 15 \\
\hline Maryland & 20 & 40 & 10 & Vermont & 25 & 50 & 10 \\
\hline Massachusetts* & 20 & 40 & 5 & Virginia & 25 & 50 & 20 \\
\hline Michigan & 20 & 40 & 10 & Washington & 25 & 50 & 10 \\
\hline Minnesota* & 30 & 60 & 10 & West Virginia & 20 & 40 & 10 \\
\hline Mississippi* & 25 & 50 & 25 & Wisconsin & 25 & 50 & 10 \\
\hline Missouri & 25 & 50 & 10 & Wyoming & 25 & 50 & 20 \\
\hline
\end{tabular}

"States that changed auto insurance minimums during the 1982-2006 period according to our research.

Unsurprisingly then, the scatter plot in figure 2 depicts a statistically significant (at the $5 \%$ level) and strong positive correlation of 0.93 between fatality rate and auto insurance minimums. The significant positive correlation persists even after removing potential outlier observations in the lower, right-hand corner of the graph. However, this correlation does not necessarily imply causality as other factors, like improving vehicle and road safety, can be responsible for much of the observed decrease in the traffic fatality rate over time. 
Figure 1

Traffic fatality rate and real value of auto insurance minimums over time

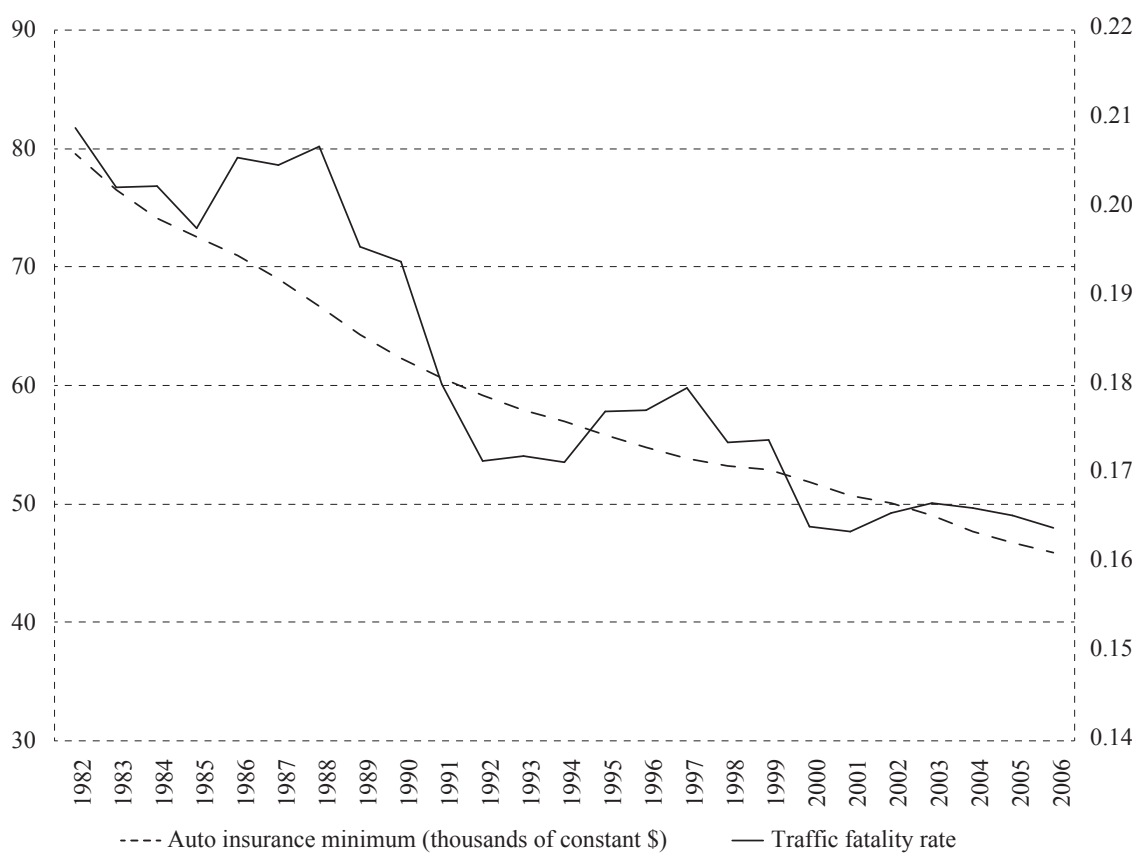

Figure 2

Traffic fatality rates and auto insurance minimums in 48 states (1982-2006)

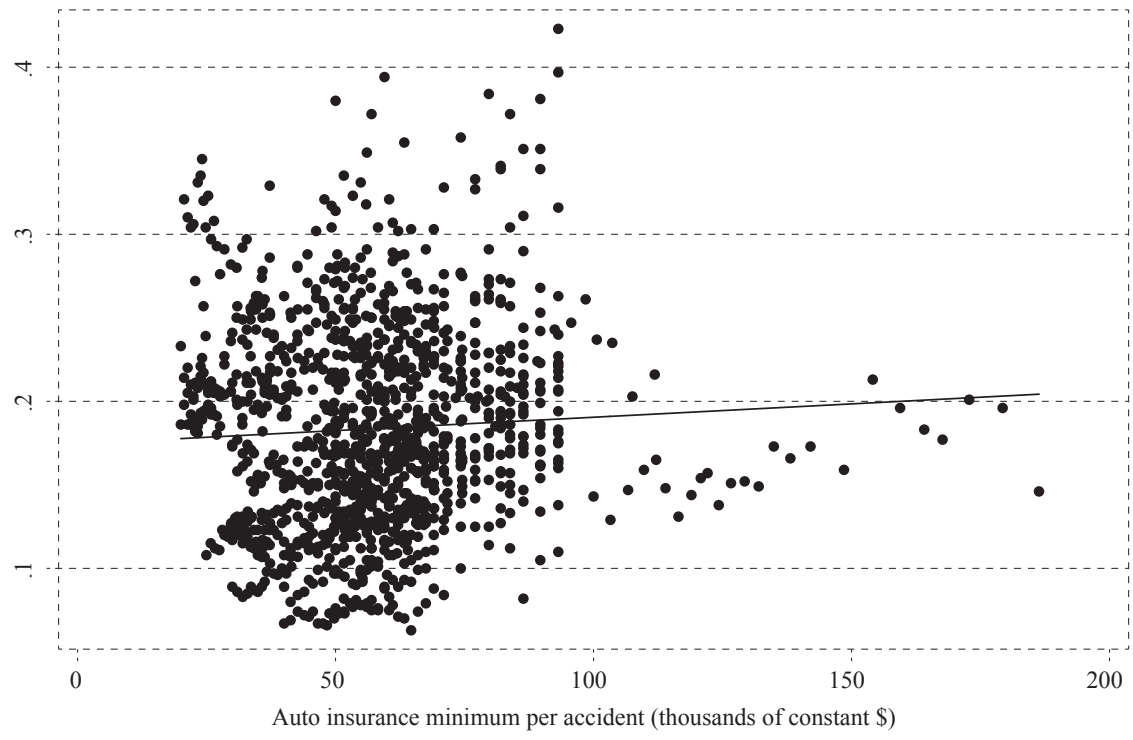

- Traffic fatality rate — Best fit line 
The empirical challenge of detecting the moral hazard effect requires separating the trend of declining traffic fatalities due to continual improvements in road and vehicle safety from policy-induced changes such as the increase in auto insurance minimums. Fortunately, policy-induced changes in auto insurance minimums that occurred in ten states during the studied time period can serve as a quasi-experiment, helping with the identification of the causal effect from policy changes. Namely, if there is a moral hazard effect, then the states that raised their auto insurance minimums should have experienced a higher traffic fatality rate than the control group, ceteris paribus.

\section{Figure 3}

Traffic fatality rates fell less in states that raised auto insurance minimums

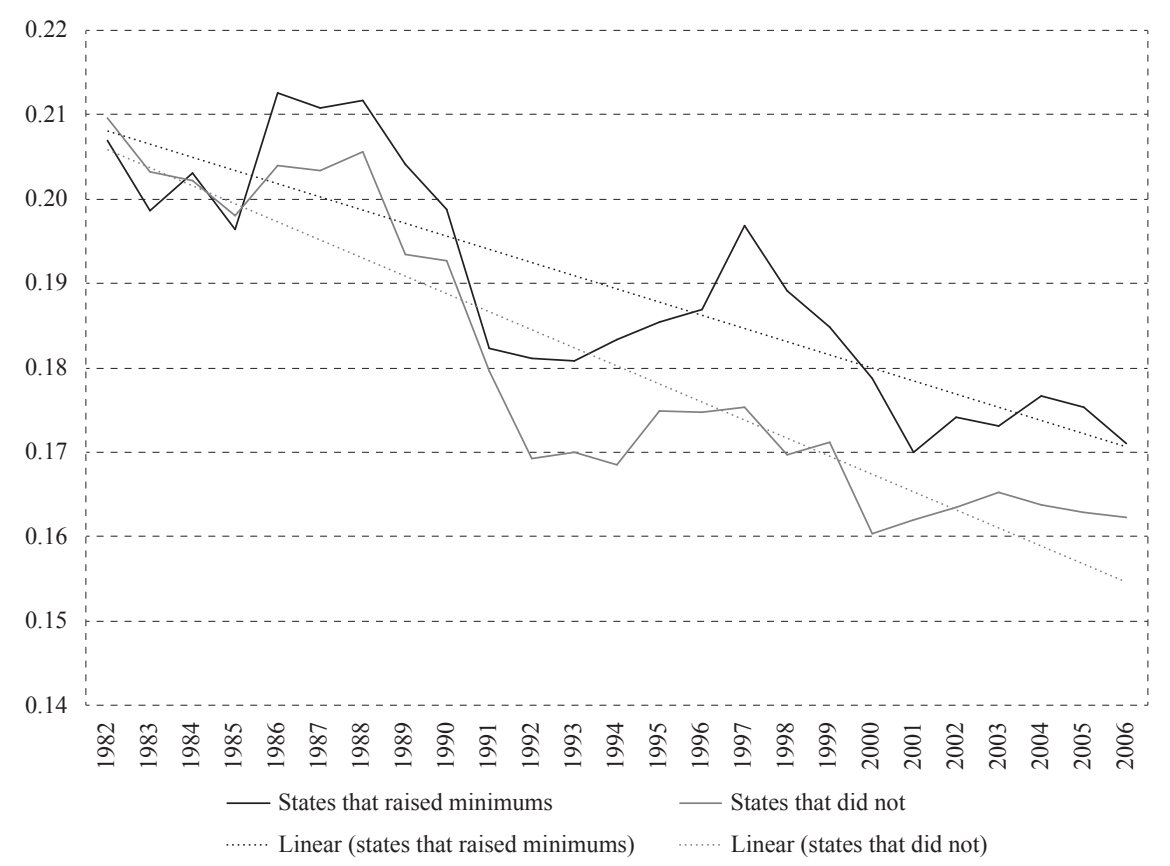

Figure 3 shows that the traffic fatality rate typically fell over time, but it fell significantly more in states that did not raise their auto insurance minimums than in those that did. The difference between the two groups' fatality rate means is statistically significant at the 5 percent level. As can be seen in the figure, the gap in traffic fatalities between the two groups of states widened more in the second half of the 1982-2006 period when several states increased their auto insurance minimums. Of course, this figure does not prove that lower auto insurance minimums cause an improvement in safety by reducing the moral hazard effect. In fact, one could argue that causality might work in the opposite direction: rising traffic fatalities may force policymakers to update their auto insurance minimums. However, we don't find any evidence in favour of the reverse-causality argument. 

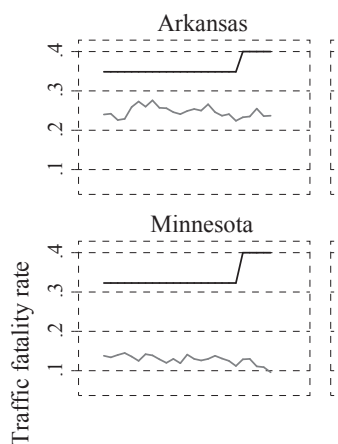

South Carolina

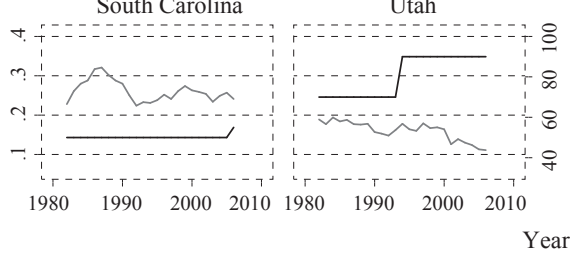

Delaware

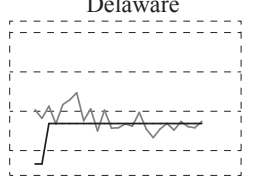

Mississippi

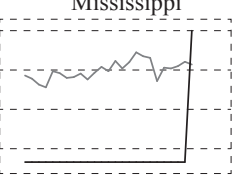

Utah
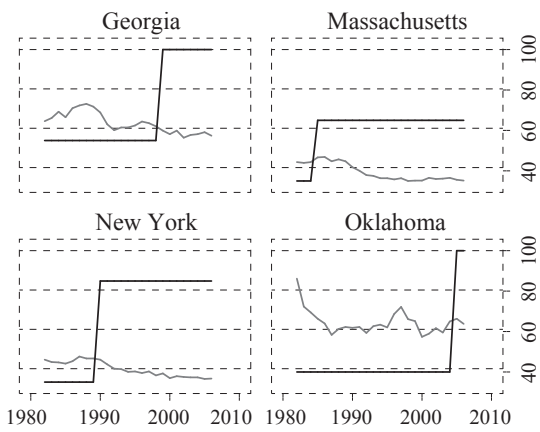

In figure 4, we show the evolution of traffic fatality rates and auto insurance minimums (in total nominal value) in the ten states that increased their auto insurance minimums during the studied time period. None of the ten states in figure 4 show a clear-cut rise in the traffic fatality rate before the increase in state auto insurance minimums. In fact, most of the ten states show a downward trend in traffic fatalities over time. It is hard to imagine that policy makers would feel pressured to increase the state auto insurance minimums if their traffic fatality rates were falling rather than rising. In the next section of this paper, we also test for the exogeneity of auto insurance minimums and fail to reject it. This result is consistent with the findings by Jeziorski, Krasnokutskaya and Ceccariniz (2015), who note that the industry's practice of pricing premiums reflects the probability of an accident rather than its severity, implying that the amount of insurance coverage appears to be unrelated to risk.

We also have a good theoretical reason to suspect that auto insurance minimums are exogenous to the traffic fatality rate or the probability of a deadly accident. Unlike insurance premiums, which in theory should reflect the probability of an accident, the minimums are typically set to cover the expected expenses in the event of an accident. The increase or decrease in the odds of an accident should not affect the amount of optimally chosen coverage, which in theory should be equal to the value of the insured assets. In other words, auto insurance minimums should be exogenous to traffic fatality rates and policy makers probably set the auto insurance liability minimums in proportion to potential damages from an accident rather than the probability of an accident. The minimums would then be proportional to the amount of expected damages, which would probably depend 
on per capita wealth or income in a given state. For this reason, the policy-induced changes in auto insurance minimums are akin to a quasi-natural experiment, making the minimums exogenous to state traffic fatality rates.

\section{TABLe 2}

Variables and sources

\begin{tabular}{|c|c|c|}
\hline Variable name & Variable description & $\begin{array}{c}\text { Mean } \\
\text { (std. dev.) }\end{array}$ \\
\hline Traffic fatality rate $^{1}$ & $\begin{array}{l}\text { Traffic fatalities divided by state population } \\
\text { measured in thousands. }\end{array}$ & $\begin{array}{c}0.18 \\
(0.06)\end{array}$ \\
\hline $\begin{array}{l}\text { Auto insurance } \\
\text { minimum }^{6}\end{array}$ & $\begin{array}{l}\text { Per accident minimum liability amount } \\
\text { (in thousands of dollars) adjusted for inflation } \\
\text { using GDP deflator. }\end{array}$ & $\begin{array}{c}59.36 \\
(23.53)\end{array}$ \\
\hline Young population share ${ }^{2}$ & $\begin{array}{l}\text { Share of people } 18-24 \text { years of age in state } \\
\text { population. }\end{array}$ & $\begin{array}{c}0.11 \\
(0.01)\end{array}$ \\
\hline Old population share ${ }^{2}$ & Share of people 65 and older in state population. & $\begin{array}{c}0.12 \\
(0.02)\end{array}$ \\
\hline Minimum drinking age ${ }^{2}$ & Minimum legal drinking age for spirits in years. & $\begin{array}{l}20.59 \\
(0.93)\end{array}$ \\
\hline Gasoline price ${ }^{3}$ & Per gallon gasoline price in constant dollars. & $\begin{array}{c}1.90 \\
(0.41)\end{array}$ \\
\hline Income per capita ${ }^{4}$ & Real GDP/total population (in thousands). & $\begin{array}{c}39.74 \\
(10.38)\end{array}$ \\
\hline Population density ${ }^{5}$ & Total population/square mile of land. & $\begin{array}{c}0.17 \\
(0.24)\end{array}$ \\
\hline Alcohol consumption ${ }^{7}$ & $\begin{array}{l}\text { Alcohol consumption in gallons per capita for } \\
\text { state population over the age of } 17 \text {. }\end{array}$ & $\begin{array}{c}2.39 \\
(0.56)\end{array}$ \\
\hline Precipitation $^{8}$ & $\begin{array}{l}\text { Average weighted annual rain and snow fall in } \\
\text { inches. }\end{array}$ & $\begin{array}{c}3.09 \\
(1.26)\end{array}$ \\
\hline Air temperature ${ }^{8}$ & $\begin{array}{l}\text { Average weighted annual air temperature in } \\
\text { Fahrenheit. }\end{array}$ & $\begin{array}{l}52.50 \\
(7.61)\end{array}$ \\
\hline Speed limit ${ }^{9}$ & $\begin{array}{l}\text { Average (rural and urban) speed limit in miles } \\
\text { per hour. }\end{array}$ & $\begin{array}{l}60.03 \\
(6.15) \\
\end{array}$ \\
\hline Crime rate ${ }^{10}$ & Overall crime rate. & $\begin{array}{c}0.05 \\
(0.01)\end{array}$ \\
\hline Primary seatbelt law ${ }^{11}$ & $\begin{array}{l}\text { Dummy variable: } 1 \text { if state has a primary } \\
\text { seatbelt law, } 0 \text { if otherwise. }\end{array}$ & $\begin{array}{c}0.22 \\
(0.42)\end{array}$ \\
\hline Compulsory insurance ${ }^{12}$ & $\begin{array}{l}\text { Dummy variable }=1 \text { if state has compulsory } \\
\text { insurance ( } 0 \text { otherwise). }\end{array}$ & $\begin{array}{c}0.73 \\
(0.44)\end{array}$ \\
\hline No-fault liability ${ }^{12}$ & $\begin{array}{l}\text { Dummy variable }=1 \text { if state has no-fault liability } \\
\text { law ( } 0 \text { otherwise). }\end{array}$ & $\begin{array}{c}0.28 \\
(0.45)\end{array}$ \\
\hline
\end{tabular}
1) FARS (2009)
2) Ponicki (2004)
7) The Beer Institute (2008)
3) EIA (2009)
8) $\operatorname{NCDC}(2017,2017 a)$
4) $B E A$ (2009)
9) IIHS (2017)
5) U.S. Census Bureau (2009)
10) Bureau of Justice Statistics (2017)
6) State-by-State Insurability Requirements (2009)
11) NHTSA (2009)
12) Cohen and Dehejia (2004) 
In order to isolate the effect of insurance minimums on the traffic fatality rate from the confounding factors, this study employs a large and diverse set of control variables suggested by previous research ${ }^{6}$ The control variables fall into the four main categories: economic (income, gasoline price, alcohol consumption), demographic (age, population density, crime rate), climatic (precipitation, temperature), and policy (compulsory, no-fault, speed limit, seatbelt, and legal drinking age laws). Variable definitions, sources, and descriptive statistics are shown in table 2. In the next section, we develop our empirical model and present the findings.

\section{EMPIRICAL MODEL AND ESTIMATES}

Analogously to Cohen and Dehejia (2004), we hypothesize that lowering the cost of personal accident liability through higher auto insurance minimums may overinsure some drivers, decreasing their incentives to drive carefully. We expect to find that states with policy-induced increases in insurance minimums should experience higher traffic fatality rates, holding everything else constant. Several assumptions need to hold for the hypothesized moral hazard effect to be observed empirically: (1) a sufficient fraction of drivers must be constrained by the minimum coverage, (2) drivers must be aware of their policy parameters, (3) higher minimums do not induce too many drivers to become uninsured, and (4) drivers respond to changes in coverage.

It has been reported that about 20 percent of drivers have minimum coverage, 13 percent are uninsured, and the median jury award for liability cases for vehicular accidents is about $\$ 20,000$ (Lieber, 2012). Considering that the average per person liability minimum is about $\$ 23,000$ (or $\$ 46,000$ per accident), states with high liability minimums may "over-insure" some drivers. These numbers suggest that a sizeable increase in auto insurance minimums may constrain a non-trivial percentage of drivers, giving some support to the first assumption.

Regarding our second and fourth assumptions, a study by Dionne, Michaud and Dahchour (2013) suggests that changes in insurance premiums do affect some policyholders' driving and learning behavior. These findings imply that sufficiently many drivers are aware of and appear to respond to changes in their policy parameters.

As for the third assumption, it is possible that some drivers may drop their auto insurance in response to higher insurance minimums, driving more carefully in order to minimize the odds of getting caught driving without coverage. The uninsured drivers may introduce a downward bias in the estimate of the moral hazard effect, which is likely to be small considering the modest percentage of drivers that might be affected by policy-induced increases in auto insurance minimums.

\footnotetext{
${ }^{6}$ The variables were chosen largely based on the studies by Leigh (2009), Asch and Levy (1990), Nelson, Bolen and Kresnow (1998), Derrig et al. (2002), Kahane (2000), Glassbrenner (2005), Beck et al. (2007), Sen (2001), Cohen and Einav (2003), Cohen and Dehejia (2004), Pulito and Davies (2009), Friedman, Hedeker and Richter (2009), and Yakovlev and Inden (2010).
} 
Regardless of the real-world viability of the aforementioned assumptions, the paper's moral hazard hypothesis can only be rejected empirically. To test this hypothesis, we estimate the following linear regression model with state and year fixed effects:

$$
y_{i t}=\alpha+y M_{i t}+X_{i t} \beta+u_{i}+v_{t}+\varepsilon_{i t}
$$

Where $Y_{i t}$ is the traffic fatality rate, $M_{i t}$ is the auto insurance minimum per accident, $X_{i t}$ is a vector of control variables that are discussed in more detail in the data section, $u_{i}$ and $v_{t}$ are state and year fixed effects, $\varepsilon_{i t}$ is the error term, while subscripts $i=1, \ldots, 50$ and $t=1982, \ldots, 2006$ represent states and years, respectively. State fixed effects help to control for unobserved time-invariant factors such as culture and geography, while year fixed effects control for common temporal effects such as improving vehicle safety and road conditions. The choice of the fixed-effects (within) estimator is supported by the Hausman random effects test, which rejects the null of no systematic difference in coefficients with 99.9 percent probability. This result implies that the model should be estimated using state fixed effects to control for unobserved heterogeneity, a common source of endogeneity bias.

In the first column of table 3 , we report the OLS estimates of the model in equation (1) with standard errors robust to heteroskedasticity and autocorrelation (i.e. clustered standard errors). The coefficient estimates are reported as elasticities (calculated at variables' mean values) for ease of interpretation. The coefficient estimate for auto insurance minimum per accident is positive, as expected, and statistically significant at the ten percent level. Its elasticity value of 0.096 implies that a ten percent increase in the auto insurance minimum amount is associated with almost one percent rise in the traffic fatality rate, on average.

In column two of table 3, we report the OLS estimates of the model in equation (1) with Driscoll-Kraay (1998) standard errors that are robust to the general forms of autocorrelation, heteroskedasticity, and contemporaneous correlation, which have all been detected in our data. ${ }^{7}$ This regression also yields a statistically significant (now at the one percent level) positive coefficient of 0.096 for auto insurance minimum per accident.

To correct for potential outlier bias we also estimate the model in equation (1) via "robust" regression, which is basically a re-weighted OLS. As can be seen in figure 2, there might be some outliers in the data that may bias the conventional OLS estimates. ${ }^{8}$ The "robust" regression results shown in column three of table 3 yield a statistically significant (at the one percent level) and positive elasticity estimate of 0.109 for insurance minimums.

\footnotetext{
${ }^{7}$ A Breusch-Pagan/Cook-Weisburg test indicates the presence of groupwise heteroscedasticity. Arellano-Bond and Wooldridge tests indicate the presence of autocorrelation in the residuals. The Pesaran test detects contemporaneous correlation. The residuals were also tested for non-stationarity using the Pesaran, Shin W-stat, ADFFisher Chi-square, and PP-Fisher Chi-square tests, all of which rejected the null hypothesis of non-stationarity. ${ }^{8}$ According to the Hadi $(1992,1994)$ outlier test, about 9 percent of our observations could be considered as outliers.
} 
TABle 3

Determinants of traffic fatality rates in 48 states (1982-2006)

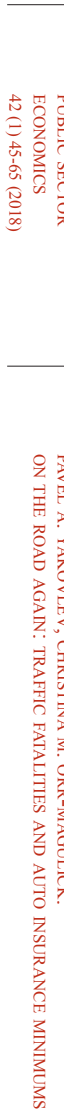

Estimator

FE OLS standard error

Clustered Driscoll-Kraa

Auto insurance

$0.096 *$

$0.096 * * *$

minimum

Compulsory

(0.052)

(0.026)

insurance

0.01

0.01

$(0.026)$

$0.108 * *$

No-fault liability

$(0.017)$

(0.012)

$0.019 * *$

$(0.051)$

Primary seatbelt law

$(0.012)$

(0.004)

(0.008)

$-0.005$

Primary seatbelt law

$-0.009 *$

$(0.004)$

$0.023 * * *$

0.013

$\frac{(0.005)}{0.132} \frac{(0.003)}{0.132^{* *}} \frac{(0.002)}{0.179^{* * *}} \frac{(0.003)}{0.170^{* *}}$

\begin{tabular}{|c|c|c|c|c|}
\hline Speed limit & $(0.123)$ & $(0.059)$ & $(0.047)$ & $(0.084)$ \\
\hline \multirow{2}{*}{$\begin{array}{l}\text { Minimum drinking } \\
\text { age }\end{array}$} & 0.179 & $0.179 * *$ & 0.062 & 0.242 \\
\hline & $(0.230)$ & $(0.088)$ & $(0.117)$ & $(0.331)$ \\
\hline \multirow{2}{*}{$\begin{array}{l}\text { Alcohol } \\
\text { consumption }\end{array}$} & $0.766^{* * *}$ & $0.766 * * *$ & $0.765^{* * *}$ & $0.610 * * *$ \\
\hline & $(0.093)$ & $(0.091)$ & $(0.050)$ & $(0.109)$ \\
\hline \multirow{2}{*}{ Income per capita } & $0.870 * * *$ & $0.870 * * *$ & $0.676^{* * *}$ & $0.603 * * *$ \\
\hline & $(0.169)$ & $(0.090)$ & $(0.076)$ & $(0.101)$ \\
\hline \multirow{2}{*}{ Gasoline price } & 0.238 & 0.238 & 0.238 & -0.234 \\
\hline & $(0.351)$ & $(0.184)$ & $(0.181)$ & $(0.224)$ \\
\hline \multirow{2}{*}{ Population density } & -0.053 & $-0.053 *$ & $-0.058 *$ & -0.070 \\
\hline & $(0.086)$ & $(0.027)$ & $(0.035)$ & $(0.053)$ \\
\hline \multirow{2}{*}{$\begin{array}{l}\text { Young population } \\
\text { share }\end{array}$} & 0.07 & $0.07 *$ & 0.00737 & $0.139 *$ \\
\hline & $(0.088)$ & $(0.036)$ & $(0.041)$ & $(0.078)$ \\
\hline \multirow{2}{*}{$\begin{array}{l}\text { Old population } \\
\text { share }\end{array}$} & -0.082 & $-0.082 *$ & -0.044 & $-0.177 * *$ \\
\hline & $(0.110)$ & $(0.043)$ & $(0.048)$ & $(0.088)$ \\
\hline \multirow{2}{*}{ Crime rate } & 0.0581 & 0.0581 & $0.055^{* *}$ & 0.007 \\
\hline & $(0.044)$ & $(0.037)$ & $(0.026)$ & $(0.036)$ \\
\hline \multirow{2}{*}{ Precipitation } & $-0.085 * * *$ & $-0.085 * * *$ & $-0.078 * * *$ & $-0.087 * * *$ \\
\hline & $(0.019)$ & $(0.019)$ & $(0.018)$ & $(0.020)$ \\
\hline \multirow{2}{*}{ Air temperature } & -0.125 & -0.125 & $-0.258^{*}$ & -0.008 \\
\hline & $(0.158)$ & $(0.165)$ & $(0.151)$ & $(0.179)$ \\
\hline $\begin{array}{l}\text { Lagged dependent } \\
\text { variable }\end{array}$ & - & - & - & $\begin{array}{l}0.344 * * * \\
(0.051)\end{array}$ \\
\hline R-squared & 0.62 & 0.62 & 0.95 & - \\
\hline \multicolumn{5}{|c|}{$\begin{array}{l}* * * \text { Indicates significance at } 1 \%, * * \text { at } 5 \% \text {, and } * \text { at } 10 \% . \text { Dependent variable: traffic fatality } \\
\text { rate. The reported coefficients are elasticities computed as d(lny)/d(lnx) at variables'means (dum- } \\
\text { mies are treated as continuous variables for calculating the means). All models include state and } \\
\text { year fixed effects, but their coefficients, along with a constant, are not reported. Due to the lack } \\
\text { of consistent annual precipitation and temperature data, Alaska and Hawaii are excluded from } \\
\text { the sample, resulting in } 48 \text { contiguous states over } 25 \text { years or } 1,200 \text { observations. }\end{array}$} \\
\hline
\end{tabular}


While the last three regression models have shown encouraging consistency in the estimates for auto insurance minimums, they could still suffer from another type of endogeneity bias - reverse causality. Fortunately, we have good theoretical and empirical reasons to argue that auto insurance minimums are exogenous. As discussed in more detail in the data section of this paper, economic theory suggests that the auto insurance minimums are likely to be set in proportion to the expected damages from an accident rather than accident probability, making them exogenous to past traffic fatalities. Similarly, Jeziorski, Krasnokutskaya and Ceccariniz (2015) find that the insurance premiums reflect the probability of accidents rather than their severity, implying that the damages are unrelated to an individual's ability or risk. We also perform a formal empirical test of exogeneity of auto insurance minimums in the following regression model, which is estimated via a dynamic general method of moments (GMM):

$$
\Delta Y_{i t}=\alpha+\rho \Delta Y_{i t-1}+y \Delta \hat{M}_{i t}+\Delta X_{i t} \beta+v_{t}+\varepsilon_{i t} .
$$

This Arellano and Bond (1991) dynamic GMM model features robust standard errors and year dummies (i.e. time fixed effects) because the first-differencing procedure removes all time-invariant heterogeneity (i.e. state fixed effects) and first-order autocorrelation in the error term. ${ }^{9}$ According to Roodman (2006), the general method of moments (GMM) estimator is well suited for dynamic models with small-T and large-N dimensions, heteroskedastic and endogenous error structure. Arellano and Bond (1991) and Holtz-Eakin, Newey and Rosen (1988) argue that the endogenous variables can sometimes be instrumented with their own lagged values as "internal" instruments. Similarly to Jeziorski, Krasnokutskaya and Ceccariniz (2015), we instrument for potentially endogenous insurance minimums with their own lagged values in levels ( $t-2$ and deeper). The Sargan/ Hansen test fails to reject the null hypothesis of instrument over-identification ( $p$ value of 0.64 ), implying that the chosen instruments are sufficiently correlated with the possibly endogenous variables, but uncorrelated with the error term. Furthermore, we fail to reject the null hypothesis (p-value of 0.25 ) that the auto insurance minimums are exogenous. ${ }^{10}$

The GMM model yields a statistically significant (at the five percent level) and positive elasticity coefficient of 0.108 , which further corroborates our hypothesis that higher auto insurance minimums increase the traffic fatality rate (see column 4 in table 3). While the estimated elasticity coefficients for auto insurance minimums are modest in magnitude (i.e. relatively inelastic) across all four models, ranging from 0.096 to 0.109 , their impact on the traffic fatality rate is still noteworthy considering the non-trivial number of deadly collisions that occur every year. Our average elasticity estimate of about 0.1 implies that a $\$ 6,000$ mandated

\footnotetext{
${ }^{9}$ It is important to point out that the Arellano-Bond test fails to reject (with p-value of 0.23 ) the null hypothesis of nonexistent second-order autocorrelation in the error term, a required assumption for GMM models. ${ }^{10}$ We use a generalized version of the Durbin-Wu-Hausman (DWH) test of the endogeneity of regressors, implemented as the Hansen/Sargan/C test statistic in the GMM model developed by Baum, Schaffer and Stillman (2003).
} 
increase in the auto insurance per-accident liability minimum is likely to result in one extra death from traffic collisions, on average. This mandatory increase in coverage comes at a high social cost considering that the median value of a statistical life estimated in the wage-risk studies ${ }^{11}$ to be about $\$ 7$ million. A couple of recent papers find corroborating evidence of costly moral hazard responses to changes in auto insurance coverage for drivers. For example, Jeziorski, Krasnokutskaya and Ceccariniz (2015) estimate that a $\$ 50$ rise in the cost of a claim for an average policy reduces the claim probability by roughly a 0.1 percentage point. Similarly, Weisburd (2015) estimates that a $\$ 100$ reduction in accident claim costs for drivers results in a 1.7 percentage point increase in the probability of an accident or, equivalently, a 10 percent increase in auto accidents. These findings show that significant social welfare costs can arise due to moral hazard from over-generous auto insurance coverage.

Looking at all the models in table 3 , it is clear that several control variables also have significant associative effects on the traffic fatality rate. Namely, alcohol consumption and income per capita have relatively large and statistically significant positive effects on the traffic fatality rate across all models. The positive coefficient for income per capita is consistent with the idea of driving being a normal good: rising real incomes may put more drivers on the road, increasing the probability of deadly collisions. Precipitation has a significant negative effect on the traffic fatality rate across all models. Primary seat belt law is negative and statistically significant in the first three out of four regression models. In some models, the shares of young and old populations appear to have the expected positive and negative, respectively, statistically significant relationships with the traffic fatality rate. No-fault liability law is positive and statistically significant also in the first three out of four regression models, supporting previous findings in the literature of possible moral hazard. While compulsory insurance appears statistically significant in only one regression model, it has a positive coefficient, which is also consistent with the moral hazard hypothesis.

\section{CONCLUSION}

This study examines empirically whether higher state auto insurance minimums create a moral hazard problem by effectively over-insuring some drivers and lowering their incentives to drive more carefully. After controlling for numerous contributing factors and possible endogeneity of auto insurance minimums, we find a statistically significant, positive relationship between the traffic fatality rate and state auto insurance minimums. This relationship retains its sign and statistical significant across all of our regression models. The estimated elasticity coefficient for auto insurance liability minimum per accident ranges from 0.096 to 0.109 , implying that a ten percent increase in auto insurance minimums is associated with about one percent increase in the traffic fatality rate, on average. In other words, a $\$ 6,000$ increase in per-accident liability minimum is likely to result in

\footnotetext{
${ }^{11}$ See Viscusi (2008) for a review of life valuation methods and findings.
} 
one more traffic fatality. With the average value of a statistical life of about $\$ 7$ million, this seems like a questionable tradeoff.

Several American states are currently considering increasing their auto insurance minimums given that the dollar amounts have not been indexed to inflation for many years and have declined in real value over time. If our estimates are correct, higher auto insurance minimums may increase traffic collisions and fatalities and reduce social welfare. We also find that no-fault and compulsory insurance laws may have significant positive effects on traffic fatalities, which is consistent with previous findings. Generally speaking, our findings provide additional evidence for the existence of moral hazard in the auto insurance industry.

\section{Disclosure statement}

No potential conflict of interest was reported by the authors. 


\section{REFERENCES}

1. Abbring, J., Chiappori, P. A. and Pinquet, J., 2003b. Moral Hazard and Dynamic Insurance Data. Journal of the European Economic Association, 1(3), pp. 767-820. doi: 10.1162/154247603322493159

2. Abbring, J. H. [et al.], 2003. Adverse selection and moral hazard in insurance: Can dynamic data help to distinguish? Journal of the European Economic Association, (1), pp. 512-521.

3. Abbring, J. H., Chiappori, P. A. and Zavadil, T., 2008. Better safe than sorry? Ex ante and ex post moral hazard in dynamic insurance data. Discussion Paper, No. 2008-77.

4. Akerlof, G. A., 1970. The Market for 'Lemons': Quality Uncertainty and the Market Mechanism. Quarterly Journal of Economics, 84(3), pp. 488-500. doi: $10.2307 / 1879431$

5. Arellano, M. and Bond, S., 1991. Some tests of specification for panel data: Monte Carlo evidence and an application to employment equations. Review of Economic Studies, 58(2), pp. 277-297. doi: 10.2307/2297968

6. Arrow, K. J., 1963. Uncertainty and the welfare economics of medical care. American Economic Review, 53(5), pp. 941-973.

7. Arrow, K. J., 1970. Insurance, Risk and Resource Allocation in: K. J. Arrow. Essays in the Theory of Risk Bearing. Amsterdam: North Holland, pp. 134-143.

8. Asch, P. and Levy, D., 1990. Young Driver Fatalities: The Roles of Drinking Age and Drinking Experience. Southern Economic Journal, 57(2), pp. 512-520. doi: $10.2307 / 1060627$

9. Baum, C. F., Schaffer, M. E. and Stillman, S., 2003. Instrumental variables and GMM: Estimation and testing. Stata Journal, 3(1), pp. 1-31.

10. BEA, 2009. Gross Domestic Product by State. Washington: The Bureau of Economic Analysis.

11. Beck, L. F. [et al.], 2007. Associations Between Sociodemographics and Safety Belt Use in States With or Without Primary Enforcement Laws. American Journal of Public Health, 97(9), pp. 1619-1624. doi: 10.2105/AJPH.2006.092890

12. Bureau of Justice Statistics, 2017. Property Crime and Violent Crime Statistics. Washington: Bureau of Justice Statistics.

13. Calkins, L. N. and Zlatoper, T. J., 2001. The Effects of Mandatory Seat Belt Laws on Motor Vehicle Fatalities in the United States. Social Science Quarterly, 82(4), pp. 716-732. doi: 10.1111/0038-4941.00055

14. Cohen, A. and Dehejia, R., 2004. The Effect of Automobile Insurance and Accident Liability Laws on Traffic Fatalities. The Journal of Law and Economics, 47(2), pp. 357-393. doi: 10.1086/422978

15. Cohen, A. and Einav, L., 2003. The Effects of Mandatory Seat Belt Laws on Driving Behavior and Traffic Fatalities. The Review of Economics and Statistics, 85(4), pp. 828-843. doi: 10.1162/003465303772815754

16. Cohen, A. and Siegelman, P., 2010. Testing for Adverse Selection in Insurance Markets. Journal of Risk and Insurance, 77(1), pp. 39-84. doi: 10.1111/ j.1539-6975.2009.01337.x 
17. Cummins, J. D., Weiss, M. A. and Phillips, R. D., 2001. The Incentive Effects of No Fault Automobile Insurance. The Journal of Law and Economics, 44(2), pp. 427-464. doi: 10.1086/322818

18. Derrig, A. R. [et al.], 2002. The Effect of Population Safety Belt Usage Rates on Motor Vehicle-Related Fatalities. Accidents Analysis and Prevention, 34(1), pp. 101-110. doi: 10.1016/S0001-4575(01)00004-5

19. Dionne, G. [et al.], 2005. The Role of Memory in Long-Term Contracting with Moral Hazard: Empirical Evidence in Automobile Insurance. THEMA Working Papers.

20. Dionne, G. [et al.], 2011. Incentive Mechanisms for Safe Driving: a Comparative Analysis with Dynamic Data. The Review of Economics and Statistics, 93(1), pp. 218-227. doi: 10.1162/REST_a_00054

21. Dionne, G., Michaud, P-C. and Dahchour, M., 2013. Separating Moral Hazard From Adverse Selection And Learning in Automobile Insurance: Longitudinal Evidence From France. Journal of the European Economic Association, 11(4), pp. 897-917. doi: 10.1111/jeea.12018

22. Driscoll, J. C. and Kraay, A. C., 1998. Consistent Covariance Matrix Estimation with Spatially Dependent Panel Data. Review of Economics and Statistics, 80(4), pp. 549-560. doi: 10.1162/003465398557825

23. EIA, 2009. Retail Gas Prices. Washington: U.S. Energy Information Administration.

24. Friedman, L. S., Hedeker, D. and Richter, E. D., 2009. Long-Term Effects of Repealing the National Maximum Speed Limit in the United States. American Journal of Public Health, 99(9), pp. 1626-1631. doi: 10.2105/AJPH.2008.153726

25. Garbacz, C., 1990a. Estimating Seat Belt Effectiveness with Seat Belt Usage Data from the Center for Disease Control. Economics Letters, 34(1), pp. 83-88. doi: 10.1016/0165-1765(90)90186-5

26. Garbacz, C., 1990b. How Effective is Automobile Safety Legislation? Applied Economics, 22(12), pp. 1705-1714. doi: 10.1080/00036849000000076

27. Garbacz, C., 1991. Impact of the New Zealand Seat Belt Law. Economic Inquiry, 29(2), pp. 310-316. doi: 10.1111/j.1465-7295.1991.tb01273.x

28. Garbacz, C., 1992. More Evidence on the Effectiveness of Seat Belt Laws. Applied Economics, 24(3), pp. 313-315. doi: 10.1080/00036849200000144

29. Glassbrenner, D., 2005. Safety Belt Use in 2004 - Demographic Results. Washington: DC: US Department of Transportation. DOT HS 809848.

30. Hadi, A., 1992. Identifying Multiple Outliers in Multivariate Data. Journal of the Royal Statistical Society. Series B (Methodological), 54(3), pp. 761-771.

31. Hadi, A., 1994. A Modification of a Method for the Detection of Outliers in Multivariate Samples. Journal of the Royal Statistical Society. Series B (Methodological), 56(2), pp. 393-396.

32. Harless, D. W. and Hoffer, G. E., 2003. Testing for Offsetting Behavior and Adverse Recruitment Among Drivers of Airbag-Equipped Vehicles. Journal of Risk and Insurance, 70(4), pp. 629-650. doi: 10.1046/j.0022-4367.2003.00068.x

33. Holmstrom, B., 1979. Moral Hazard and Observability. The Bell Journal of Economics, 10(1), pp. 74-92. doi: 10.2307/3003320 
34. Holtz-Eakin, D., Newey, W. and Rosen, H. S., 1988. Estimating vector autoregressions with panel data. Econometrica, 56(69), pp. 1371-1395. doi: $10.2307 / 1913103$

35. IIHS, 2017. Maximum Posted Speed Limits. Arlington: Insurance Institute for Highway Safety.

36. Israel, M., 2004. Do We Drive More Safely When Accidents are More Expensive? Identifying Moral Hazard from Experience Rating Schemes. Working Paper, No. 43. The Center for the Study of Industrial Organization at Northwestern University.

37. Jeziorski, P., Krasnokutskaya, E. and Ceccariniz, O., 2015. Adverse Selection and Moral Hazard in the Dynamic Model of Auto Insurance. Mimeo.

38. Kahane, C. J., 2000. Fatality Reduction by Safety Belts for Front-Seat Occupants of Cars and Light Trucks: Updated and Expanded Estimates Based on 1986-99 FARS Data. Washington, DC: US Department of Transportation.

39. Kochanowski, P. S. and Young, M. V., 1985. Deterrent Aspects of No-Fault Automobile Insurance: Some Empirical Findings. The Journal of Risk and Insurance, 52(2), pp. 269-288. doi: 10.2307/252515

40. Landes, E., 1982. Insurance, Liability, and Accidents: A Theoretical and Empirical Investigation of the Effect of No-Fault Accidents. The Journal of Law and Economics, 25(1), pp. 49-65. doi: 10.1086/467006

41. Leigh, A., 2009. Precipitation, Profits, and Pile-Ups. CEPR Discussion Papers, No. 629.

42. Lieber, R., 2012. How to Know if You Have Enough Auto Insurance. New York Times, August 25, 2012.

43. Logue, K. D. and Ben-Shahar, O., 2012 Outsourcing Regulation: How Insurance Reduces Moral Hazard. Coase-Sandor Institute for Law \& Economics Working Paper, No. 593.

44. Ma, Y. and Schmit, J., 2000. Factors Affecting the Relative Incidence of Uninsured Motorist Claims. The Journal of Risk and Insurance, 67(2), pp. 281-294. doi: 10.2307/253776

45. NCDA, 2017. Average Annual Precipitation. Asheville: National Centers for Environmental Information.

46. NCDA 2017a. Average Annual Temperature. Asheville: National Centers for Environmental Information.

47. Nelson, D. E., Bolen, J. and Kresnow, M., 1998. Trends in Safety Belt Use by Demographics and Type of State Safety Belt Law, 1987 through 1993. American Journal of Public Health, 88(2), pp. 245-249. doi: 10.2105/AJPH.88.2.245

48. NHTSA, 2009. Fatal Accident Reporting System (FARS).

49. NHTSA, 2009a. States with Primary Seatbelt Laws (to 2004). Washington: National Highway Traffic Safety Administration.

50. Pauly, M. V., 1968. The Economics of Moral Hazard: Comment. American Economic Review, 58(3), pp. 531-537.

51. Pauly, M. V., 1974. Overinsurance and public provision of insurance: The roles of moral hazard and adverse selection. Quarterly Journal of Economics, 88(1), pp. 44-62. doi: 10.2307/1881793 
52. Peltzman, S., 1975. The Effects of Automobile Safety Regulation. Journal of Political Economy, 83(4), pp. 667-725. doi: 10.1086/260352

53. Ponicki, W. R., 2004. Statewide Availability Data System II: 1933-2003. National Institute on Alcohol Abuse and Alcoholism. Research Center Grant P60 AA006282-23. Berkeley, CA: Pacific Institute for Research and Evaluation, Prevention Research Center.

54. Puelz, R. and Snow, A., 1994. Evidence on Adverse Selection: Equilibrium Signaling and Cross Subsidization on the Insurance Market. Journal of Political Economy, 102(2), pp. 236-257. doi: 10.1086/261930

55. Pulito, J. and Davies, A., 2009. Government Run Liquor Stores: The Social Impact of Privatization. The Commonwealth Foundation Policy Brief, 21(3), pp. 1-16.

56. Risa, A. E., 1994. Adverse Incentives from Improved Technology: Traffic Safety Regulation in Norway. Southern Economic Journal, 60(4), pp. 844-857. doi: $10.2307 / 1060424$

57. Roodman, D., 2006. How to do xtabond2: an introduction to 'Difference' and 'System' GMM in Stata. Center for Global Development Working Paper, No. 103.

58. Rothschild, M. and Stiglitz, J. E., 1976. Equilibrium in competitive insurance markets: An essay on the economics of imperfect information. Quarterly Journal of Economics, 90(4), pp. 629-649. doi: 10.2307/1885326

59. Sen, A., 2001. An Empirical Test of the Offset Hypothesis. Journal of Law and Economics, 44(2), pp. 481-510. doi: 10.1086/322051

60. Shavell, S., 1979. On Moral Hazard and Insurance. The Quarterly Journal of Economics, 93(4), pp. 541-562. doi: 10.2307/1884469

61. Sobel, R. S. and Nesbit, T. M., 2007. Automobile safety regulation and the incentive to drive recklessly: Evidence from NASCAR. Southern Economic Journal, 74(1), pp. 71-84.

62. State-by-State Insurability Requirements, 2009. Available at: $<$ www.carinsurancerates.com>.

63. The Beer Institute, 2009. Brewers Almanac 2008. Washington: The Beer Institute.

64. U.S. Census Bureau. 2009. Statistical Abstract. Washington: Census Bureau.

65. Viscusi, W. K., 2008. How to value a life. Journal of economics and finance, 32(4), pp. 311-323. doi: 10.1007/s12197-008-9030-x

66. Weisburd, S., 2015. Identifying moral hazard in car insurance contracts. Review of Economics and Statistics, 97(5), pp. 301-313. doi: 10.1162/REST_a_00448

67. Wilson, C., 1977. A Model of Insurance Markets with Incomplete Information, Journal of Economic Theory, 16(2), pp. 167-207. doi: 10.1016/00220531(77)90004-7

68. Yakovlev, P. and Inden, M., 2010. Mind the Weather: A Panel Data Analysis of Time-Invariant Factors and Traffic Fatalities. Economics Bulletin, 30(4), pp. 2685-2696.

69. Zador, P. and Lund, A., 1986. Re-Analyses of the Effects of No-Fault Auto Insurance on Fatal Crashes. The Journal of Risk and Insurance, 53(2), pp. 226-241. doi: $10.2307 / 252373$ 